\title{
Oligella infections: Case report and review of the literature
}

\author{
MAHIN BAQI MD FRCPC, TONY MAZZULLI MD FRCPC
}

\begin{abstract}
M BAQI, T MAZZULLI. Oligella infections: Case report and review of the literature. Can J Infect Dis 1996;7(6):377379. A case of Oligella ureolytica infection of a cervical lymph node is presented and previous cases of oligella infection reported in the literature are reviewed. Underlying malignancy and urinary tract obstruction were observed in many of the cases. All patients responded to antimicrobial therapy and, in those cases associated with urinary tract obstruction, surgical relief of the obstruction. The microbiology and clinical features of oligella infections are reviewed.
\end{abstract}

Key Words: Lymph node infection, Oligella ureolytica

\section{Infections à Oligella : rapport de cas et synthèse de la littérature}

RÉSUMÉ : Un cas d'infection à Oligella urealytica d'un ganglion lymphatique cervical est présenté et des cas antérieurs d'infection à Oligella sont signalés dans la littérature et passés en revue ici. Une néoplasie sous-jacente et une obstruction des voies urinaires ont été observées dans de nombreux cas. Tous les patients ont répondu au traitement antimicrobien et les cas associés à l'obstruction des voies urinaires ont été traités chirurgicalement. La microbiologie et les caractéristiques cliniques des infections à Oligella sont passés en revue.

$\mathrm{T}$ wo species comprise the genus Oligella, named as such because of the small size of the bacilli on Gram stain. The more clinically prominent species, Oligella ureolytica, previously known as Centers for Disease Control and Prevention (CDC) group IVe, hydrolyses urea easily. The less common species is Oligella urethralis, which was formerly classified as Moraxella urethralis or CDC group M-4 (1). Clinical infections due to these organisms are rare. In this article, we report a case of $O$ ureolytica infection of a cervical lymph node and review the literature for previously reported cases of oligella infections. We believe this to be the first reported case of $O$ ureolytica isolated from a cervical lymph node.

\section{CASE PRESENTATION}

A 49-year-old woman was diagnosed with chronic lymphocytic leukemia in June 1990. Six months after her diagnosis, she presented with massive intra-abdominal adenopathy and was treated with six cycles of cyclophosphamide, hydroxydaunomycin, vincristine and prednisone (CHOP) chemotherapy with good response. Chlorambucil was started in October 1994 when leukocytosis, splenomegaly and increasing lymphadenopathy were noted. She remained well until July 1995 when an enlarged right posterior cervical lymph node measuring $2 \times 1.5 \times 1 \mathrm{~cm}$ was noted. There were no associated fever, chills, night sweats or weight loss. She was receiving no antibiotics at the time of presentation. Hemogram showed hemoglobin $91 \mathrm{~g} / \mathrm{L}$, white blood cell count $45.1 \times 10^{9} / \mathrm{L}$ and platelets $153 \times 10^{9} / \mathrm{L}$. Bone marrow examination revealed high grade follicular small cleaved cell lymphoma. A computed tomography scan of the abdomen showed bulky celiac, peripancreatic, mesenteric and retrocrural adenopathy. A lymph node biopsy of the neck node showed high grade diffuse large cell immunoblastic lymphoma with prominent neutrophils and tumour necrosis. Fluid aspirated from the lymph node was

Departments of Microbiology, Mount Sinai and Princess Margaret Hospitals and University of Toronto, Toronto, Ontario Correspondence and reprints: Dr Tony Mazzulli, Department of Microbiology, Mount Sinai Hospital, 600 University Avenue, Toronto, Ontario M5G1X5.Telephone 416-586-4695,fax416-586-8746, tmazzulli@mtsinai.on.ca

Received for publication November 23, 1995. Accepted January 31, 1996 
TABLE 1

Clinical features of reported cases of oligella infection

\begin{tabular}{|c|c|c|c|c|c|c|}
\hline $\begin{array}{l}\text { Reference } \\
\text { (Year) }\end{array}$ & $\begin{array}{l}\text { Age } \\
(\text { years)/sex }\end{array}$ & Organism & Source & $\begin{array}{l}\text { Underlying } \\
\text { condition(s) }\end{array}$ & Treatment & Outcome \\
\hline $6(1992)$ & $83 / \mathrm{M}$ & Oligella urethralis & Knee fluid & $\begin{array}{l}\text { Rectal } \\
\text { adenocarcinoma, } \\
\text { septic arthritis }\end{array}$ & Amoxicillin & Recovered \\
\hline 7 (1993) & $75 / M$ & O urethralis & Blood, urine & $\begin{array}{l}\text { Metastatic } \\
\text { colorectal } \\
\text { cancer, } \\
\text { obstructive } \\
\text { uropathy }\end{array}$ & $\begin{array}{l}\text { Ampicillin, } \\
\text { nephrostomy }\end{array}$ & Recovered \\
\hline 8 (1993) & $40 / M$ & Oligella ureolytica & Blood & $\begin{array}{l}\text { AIDS, sacral ulcer, } \\
\text { fungemia }\end{array}$ & $\begin{array}{l}\text { Vancomycin, } \\
\text { ceftazidime, } \\
\text { tobramycin, } \\
\text { ciprofloxacin }\end{array}$ & $\begin{array}{l}\text { Responded; } \\
\text { died } \\
\text { secondary to } \\
\text { fungemia }\end{array}$ \\
\hline 9 (1978) & $55 / F$ & O ureolytica & Blood, urine & $\begin{array}{l}\text { Uterine } \\
\text { adenocarcinoma, } \\
\text { obstructive } \\
\text { uropathy }\end{array}$ & $\begin{array}{l}\text { Cefazolin, } \\
\text { kanamycin, } \\
\text { nephrostomy }\end{array}$ & Recovered \\
\hline $\begin{array}{l}\text { Present } \\
\text { Report } \\
(1995)\end{array}$ & $45 / F$ & O ureolytica & $\begin{array}{l}\text { Cervical lymph } \\
\text { node }\end{array}$ & $\begin{array}{l}\text { Non-Hodgkins } \\
\text { lymphoma }\end{array}$ & $\begin{array}{l}\text { TMP-SMX, } \\
\text { ciprofloxacin, } \\
\text { cephalexin }\end{array}$ & Recovered \\
\hline
\end{tabular}

M Male; F Female; TMP-SMX Trimethoprim-sulfamethoxazole

TABLE 2

Antimicrobial susceptibilities of Oligella species

\begin{tabular}{|c|c|c|c|c|c|c|c|c|c|c|}
\hline \multirow{2}{*}{$\begin{array}{l}\text { Organism } \\
\text { (Reference) }\end{array}$} & \multicolumn{10}{|c|}{ Antimicrobial susceptibility* } \\
\hline & A & AG & Ak & Cip & Ctx & Ctz & $\mathrm{Cz}$ & I & Pip & T-S \\
\hline $\begin{array}{l}\text { Oligella } \\
\text { urethralis (6) }\end{array}$ & $\mathrm{S}$ & $\mathrm{S}$ & $\mathrm{S}$ & NT & S & $\mathrm{S}$ & $\mathrm{S}$ & NT & NT & S \\
\hline O urethralis (7) & $\mathrm{R}$ & S & $\mathrm{S}$ & $\mathrm{R}$ & NT & NT & NT & S & $\mathrm{R}$ & $\mathrm{S}$ \\
\hline $\begin{array}{l}\text { Oligella } \\
\text { ureolytica (8) }\end{array}$ & NT & $\mathrm{S}$ & $\mathrm{S}$ & $\mathrm{S}$ & NT & $\mathrm{R}$ & NT & $\mathrm{S}$ & $\mathrm{R}$ & $\mathrm{S}$ \\
\hline O ureolytica (9) & $\mathrm{R}$ & $\mathrm{S}$ & $\mathrm{S}$ & NT & NT & NT & NT & NT & NT & $S$ \\
\hline O ureolytica (PR) & $\mathrm{R}$ & $\mathrm{S}^{+}$ & $\mathrm{S}$ & $\mathrm{S}$ & $\mathrm{R}$ & $\mathrm{S}$ & $\mathrm{R}$ & NT & $\mathrm{R}$ & $\mathrm{S}$ \\
\hline
\end{tabular}

${ }^{*}$ Determined using disk diffusion methodology; ${ }^{\dagger}$ Sensitive to gentamicin. A Ampicillin; AG Aminoglycosides; Ak Amikacin; Cip Ciprofloxacin; Ctx Ceftriaxone; Ctz Ceftazidime; Cz Cefazolin; I Imipenem; NT Not tested or not reported; Pip Piperacillin; PR Present report; R Resistant; S Sensitive; T-S Trimethoprim-sulfamethoxazole

placed in a blood culture bottle and submitted to the microbiology laboratory for culture. Following two days of incubation, a Gram-negative bacillus was isolated. The organism was oxidase-positive, nonfermentative and motile, and it rapidly hydrolysed urea. It was identified as $O$ ureolytica by the reference public health laboratory. Susceptibility testing, done via disk diffusion and following National Committee for Clinical Laboratory Standards guidelines (2), showed that the organism was susceptible to amikacin, ciprofloxacin, trimethoprim-sulfamethoxazole (TMP-SMX), gentamicin and ceftazidime, but resistant to ampicillin, cefazolin, ceftriaxone and piperacillin. She was given a seven-day course of ciprofloxacin followed by a two-week course of TMP-SMX with minimal response. The lymph node increased in size, became more painful and began draining clear fluid. However, culture of the fluid was sterile. Surgical drainage was attempted without success. She was subsequently started on cephalexin and chemotherapy with (Cyclophosphamide, doxorubicin, etoposide, cytarabine, bleomycin, vincristine, methotrexate, prednisone (ProMace-CytaBOM). With initiation of chemotherapy, she noted a remarkable improvement, with a reduction in size, pain and drainage of the lymph node.

\section{DISCUSSION}

Oligella species are small aerobic coccoid Gram-negative bacilli that are nonsaccharolytic. $O$ ureolytica is motile by peritrichous flagella. Most strains grow on blood or MacConkey agar but require extended incubation (two to four days) before growth can be detected. The rapidity of the urease reaction (within minutes after inoculation) is a distinctive feature. The organism has positive oxidase, catalase and phenylalanine deaminase reactions and reduces nitrate to nitrite. Most other biochemical reactions are negative $(3,4)$. It has been reported that $O$ ureolytica is susceptible to aminoglycosides and cephalosporins but resistant to usual serum concentrations of ampicillin, chloramphenicol, erythromycin, penicillin G, tetracycline and TMP-SMX (5). O urethralis differs in that it is nonmotile, urease-negative, does not convert nitrate to nitrite and is generally susceptible to most antibiotics including penicillin (3).

A search of the English language literature published between January 1966 and the present on MEDLINE identified four additional case reports of oligella infection. The term 'Oligella' was used for the search from 1991 to present; 'Moraxella' was used for databases before 1991. Articles were selected if $M$ urethralis or CDC Group IVe or M-4 organisms 
were noted in the title or abstract. References from published case reports of oligella infections were also reviewed.

Table 1 shows the clinical features of cases of oligella infection reported in the literature (6-9). All patients were adults with a mean age of 60 years (range 40 to 83). All five patients had an underlying immunosuppressive condition (three with solid tumours, one with lymphoma and one with AIDS). Abdominopelvic malignancy was observed in four of five patients. Two patients had documented urinary tract obstruction predisposing them to bacteremia. All five patients responded to antibiotic therapy, although two of these patients required additional urological procedures before an adequate response was achieved.

Table 2 compares the reported antimicrobial susceptibilities by disk diffusion testing of the clinical isolates of Oligella species. Of note, all clinical isolates, including the three $O$ ureolytica species, were susceptible to TMP-SMX. This contrasts with the report by Welch et al (5) who tested 96 isolates of group IVe (O ureolytica) bacteria and found that most were resistant to usual serum concentrations of TMP-SMX. All but one patient were treated with at least one drug to which the organism was sensitive. The patient described in reference 7 was treated with ampicillin with good response despite the isolate being resistant in vitro to the drug.

\section{CONCLUSION}

Oligella infection has rarely been reported in the literature. This may be due to misidentification of the organism or uncertainty of its pathogenicity (10). The organism is most frequently recovered from urethral specimens and the urinary tract where it is a commensal organism $(3,4,7)$. Reference 3 eludes to a case at the University of Illinois Hospital where $O$ ureolytica was recovered from a patient who presented with a facial wound with facial impetigo and cellulitis, but provided no details. The likely setting of infection with Oligella species

\section{REFERENCES}

1. Rossau R, Kersters K, Falsen E, et al. Oligella, a new genus including Oligella urethralis comb. nov. (formerly Moraxella urethralis) and Oligella ureolytica sp. nov. (formerly CDC group IVe). Int J Syst Bacteriol 1987;37:198-210.

2. National Committee for Clinical Laboratory Standards. Performance Standards For Antimicrobial Disk Susceptibility Test, 5th edn. Approved Standard M2-A5. Villanova: National Committee for Clinical Laboratory Standards, 1993.

3. Koneman EW. The nonfermentative Gram-negative bacilli. In: Koneman EW, Allen SD, Janda WM, Schreckenberger PC, Winn WC, eds. Color Atlas and Textbook of Diagnostic Microbiology, 4th edn. Philadelphia: JB Lippincott Co, 1992:215-7.

4. McGowan JE. Other Gram-negative bacilli. In: Mandell GL, Douglas RG, Bennett JE, eds. Principles and Practice of Infectious Diseases, 4th edn. New York: Churchill Livingtone, 1995:2113.

5. Welch WD, Porschen RK, Luttrell B. Minimal inhibitory concentrations of 19 antimicrobial agents for 96 clinical isolates is in patients with urological disease. In our patient, however, there was no clinical or laboratory evidence to suggest any abnormality of her urinary tract. The mechanism of infection in our patient remains unclear. Oligella may be pathogenic in the face of malignancy as shown by the cases reported $(6,7,9)$. Our patient's underlying lymphoma with extensive intra-abdominal lymph node involvement may have contributed to her infection.

Infections due to oligella appear to respond quickly to antibiotics, but additional therapy such as relief of urinary tract obstruction may be required for complete resolution $(7,9)$. TMP-SMX, imipenem and aminoglycosides have good in vitro activity against these organisms. However, in vitro susceptibility testing may yield conflicting results. All five clinical isolates reported here were susceptible to TMPSMX. This is in contrast to an earlier report by Welch et al (5). As well, one patient responded to ampicillin, an antibiotic to which the organism was resistant in vitro (7), while another developed bacteremia while receiving both ciprofloxacin and TMP-SMX, antibiotics to which the organism was susceptible (8). In our patient, following therapy with ciprofloxacin and TMP-SMX, cultures of the fluid from her cervical lymph node became sterile, suggesting eradication of $O$ ureolytica. However, clinically, the lymph node appeared to increase in size and became more painful. Following therapy with cephalexin (an antibiotic to which the organism was resistant in vitro) and chemotherapy, her symptoms improved. Given that, before starting cephalexin, her cultures were sterile, it is unlikely that this antibiotic had any effect on her clinical improvement. Her response was most likely a result of the chemotherapy and reflects the fact that the major problem was her underlying lymphoma complicated by a low grade infection with $O$ ureolytica, an organism of low pathogenicity and virulence.

of group IVe bacteria. Antimicrob Agents Chemother 1983;24:432-3.

6. Mesnard R, Sire JM, Donnio PY, Riou JY, Avril JL. Septic arthritis due to Oligella urethralis. Eur J Clin Microbiol Infect Dis 1992;11:195-6.

7. Pugliese A, Pacris B, Schoch PE, Cunha BA. Oligella urethralis urosepsis. Clin Infect Dis 1993;17:1069-70.

8. Manian FA. Bloodstream infection with Oligella ureolytica, Candida krusei and Bacteroides species in a patient with AIDS. Clin Infect Dis 1993;17:290-1.

9. Rockhill RC, Lutwick LI. Group IVe-like Gram-negative bacillemia in a patient with obstructive uropathy. J Clin Microbiol 1978;8:108-9.

10. Graham DR, Band JD, Thornberry C, Hollis DG, Weaver RE. Infections caused by moraxella, Moraxella urethralis, moraxella-like groups M-5 and M-6, and Kingella kingae in the United States, 1953-1980. Rev Infect Dis 1990;12:423-31. 


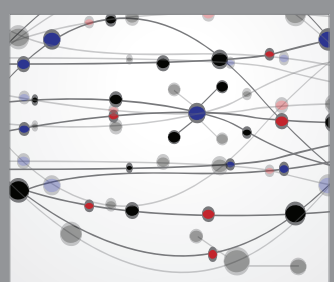

The Scientific World Journal
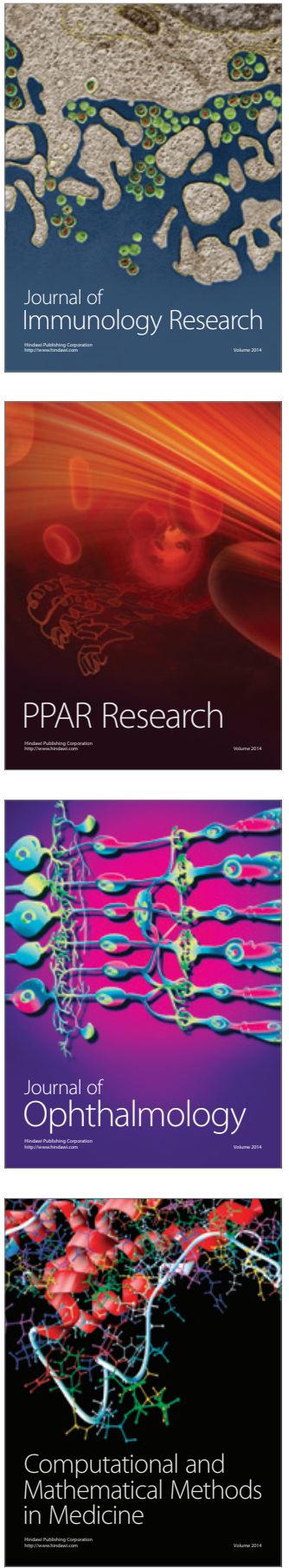

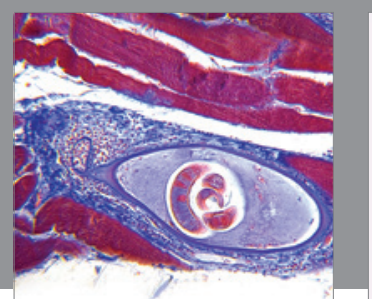

Gastroenterology Research and Practice

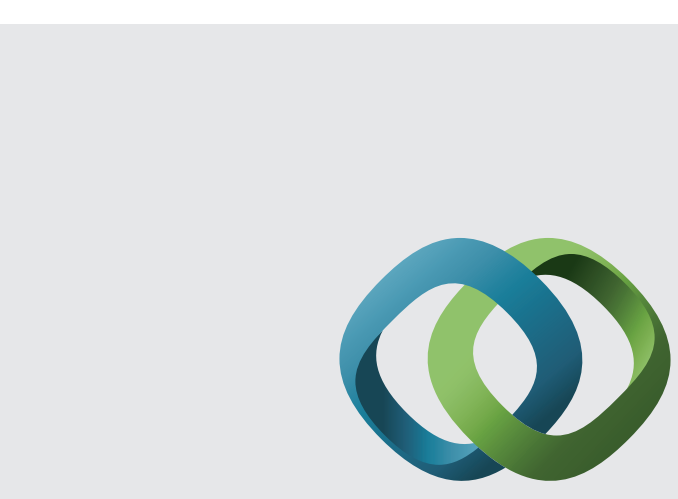

\section{Hindawi}

Submit your manuscripts at

http://www.hindawi.com
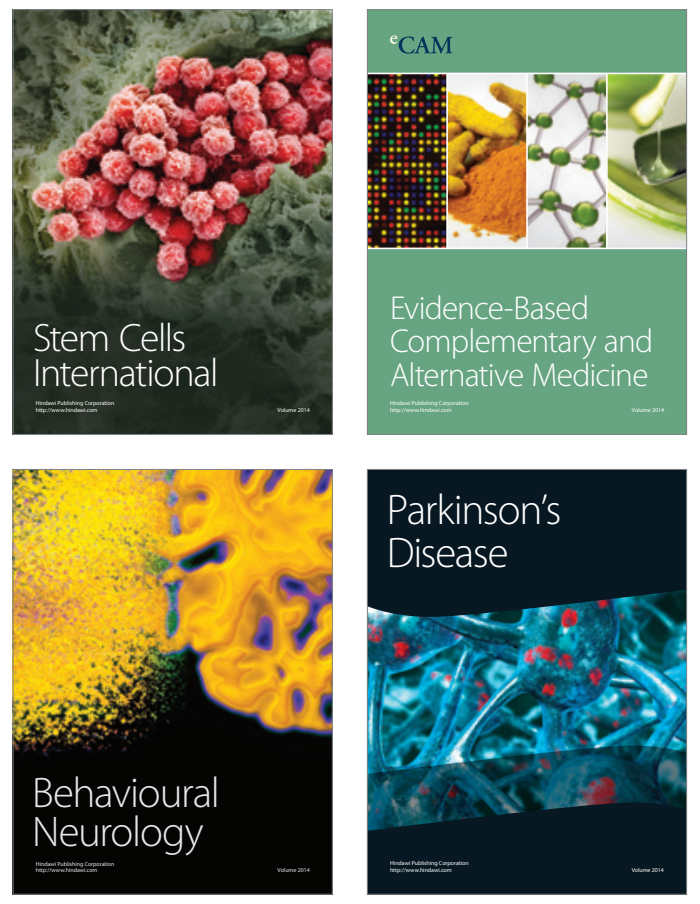
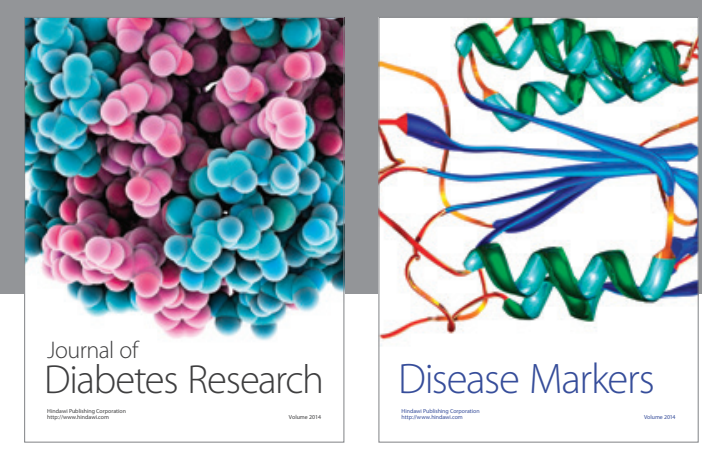

Disease Markers
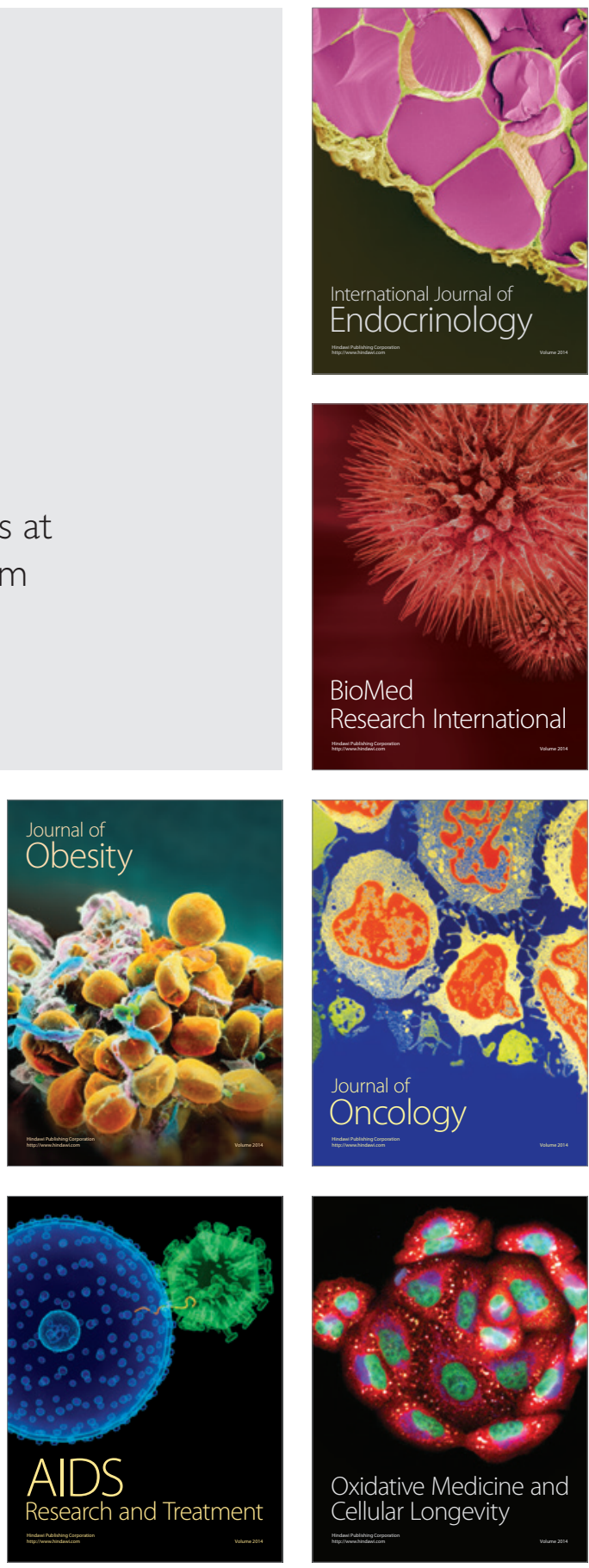